\title{
EVALUATION OF A BONE REINFORCEMENT TECHNIQUE USING FINITE ELEMENT ANALYSIS
}

\section{AVALIAÇÃO DE UMA TÉCNICA DE REFORÇO ÓSSEO COM O MÉTODO DE ELEMENTOS FINITOS}

\author{
anderson Freitas ${ }^{1,2}$, lucas Carreiro da Silva ${ }^{2}$, Nathan Drumond Vasconcelos Godinho ${ }^{2}$, Amirhossein Farvardin ${ }^{3}$, \\ Mehran Armand ${ }^{3}$, ana Patricia de Paula 4 \\ 1. Hospital Ortopédico e Medicina Especializada, Brasília, DF, Brazil. \\ 2. Hospital Regional do Gama, Brasília, DF, Brazil. \\ 3. Department of Mechanical Engineering, Johns Hopkins University, Baltimore, Maryland, USA. \\ 4. Postgraduate program, Fundação de Ensino e Pesquisa em Ciências da Saúde (FEPECS), Brasília, DF, Brazil.
}

\section{ABSTRACT}

Objectives: To compare the results of a simulated fall on the greater trochanter in the proximal portion of a synthetic femur before and after femoral reinforcement with tricalcium phosphate bone cement (TP) and polymethyl methacrylate (PMMA), using finite element analysis (FEA). Methods: Using two synthetic proximal femurs, a FEA simulating a fall on the greater trochanter was performed, using the Bi-directional Evolutionary Structural Optimization (BESO) program. For this analysis, the femurs were filled with TP and PMMA after perforations were created in the trochanteric region and neck. The results were compared with the strength values obtained from testing the control specimen, a synthetic bone without reinforcement. Results: FEA showed a value of 600 $\mathrm{N}$ prior to reinforcement. After cementing with PMMA, the load increased by $57.5 \%(945 \mathrm{~N})$, and by $53 \%(920 \mathrm{~N})$ after cementing with TP. Conclusion: Synthetic femurs gained resistance to fracture-causing forces in a simulated fall on the trochanter after bone reinforcement with PMMA and TP. Level of Evidence III; Experimental study.

Keywords: Osteoporosis. Femoral fractures. Hip.

\section{RESUMO}

Objetivos: Avaliar, com o método de elementos finitos (EF), os resultados obtidos com a simulação de queda sobre o trocanter maior, usando a porção proximal de um fêmur sintético, com a finalidade de comparar os valores obtidos antes e após técnica de reforço femoral com cimento de fosfato tricálcico (FT) e polimetilmetacrilato (PMMA). Métodos: Utilizando dois fêmures proximais sintéticos, foi realizada a análise de elementos finitos, simulando queda sobre o trocanter maior com o programa Bi-directional Evolutionary Structural Optimization (BESO). Para essa análise, os fêmures foram preenchidos, após a realização de pertuitos na região trocantérica e no colo, com FT e PMMA e os resultados foram comparados com a força obtida na análise do corpo de prova controle, osso sintético sem preenchimento. Resultados: Comparando a análise de elementos finitos antes do reforço femoral, obteve-se o valor de 600 N. Depois da cimentação com PMMA, foi observado um aumento na carga máxima da ordem de 57,5\% (945 N) e de 53\% (920 N) com o FT. Conclusão: Os fêmures sintéticos ganharam resistência aos fatores causadores de fratura em queda simulada sobre o trocanter depois do reforço ósseo com PMMA e cimento de FT. Nível de Evidência III; Estudo experimental.

Descritores: Osteoporose. Fraturas do fêmur. Quadril.

Citation: Freitas A, Silva LC, Godinho NDV, Farvardin A, Armand M, Paula AP. Evaluation of a bone reinforcement technique using finite element analysis. Acta Ortop Bras. [online]. 2018;26(1):59-62. Available from URL: http://www.scielo.br/aob.

\section{INTRODUCTION}

The World Health Organization (WHO) predicts that the incidence of osteoporotic fractures of the proximal femur will triple by 2050. In the population below 65 years of age, the incidence of femoral neck fractures is $2-4$ cases per 10,000 people. However, this value increases in the population above 70 years of age to $28 / 10,000$ in men and 64/10,000 in women. It is estimated that 6.3 million osteoporotic fractures will occur by 2050, three times the current number; half of these fractures will occur in Asia. ${ }^{1}$ In the United States, the annual cost related to treatment of osteoporotic fractures is 20 billion dollars, and hip fractures account for $60 \%$ of this cost. ${ }^{2}$ Between 1 and $1.5 \%$ of all hospital beds in Europe are occupied by patients with osteoporotic fractures. ${ }^{3}$ Twenty-two million women and 5.5 million men in the European Union (EU) received a diagnosis of osteoporosis in 2010, and 3.5 million insufficiency fractures occurred that year, 610,000 in the hip. ${ }^{3}$ The cost of treating these fractures was 37 billion euros, and is expected to increase by $25 \%$ by $2025 .{ }^{3}$ The measures of care for patients with osteoporosis in the EU have demonstrated significant results, with multidisciplinary application techniques that can reduce the occurrence of new fractures by $80 \%$. However, this

All authors declare no potential conflict of interest related to this article. 
percentage falls to $40 \%$ in preventing hip fractures. ${ }^{3}$ The mortality of patients who experience a fracture of the proximal femur after surgical treatment is 30\% in the first year; patients with these fractures have up to $30 \%$ greater risk of fracturing the contralateral femur over a 2-year period, and this value rises further over a 5-year period. ${ }^{4}$ In the case of non-simultaneous fracture of the contralateral hip, mortality reaches $64 \%$ in men and $58 \%$ in women. ${ }^{5}$ Several methods have been proposed to reduce the risk of proximal femur fracture in osteoporosis, such as adjustments to the home environment, use of hip protectors, multidisciplinary treatment, and use of medications. Many drugs of different classes have been suggested for this purpose, but even though many have shown satisfactory results in preventing fractures (approximately 50\% reduction in new osteoporotic fractures and $40 \%$ reduction in hip fractures), they have undesirable characteristics such as adverse effects with long-term use, high cost, and contraindications. ${ }^{6}$ The reduction rates are influenced by sex, and according to published studies, this rate is always observed in women but not always in men. ${ }^{7}$

Bone strengthening using polymethyl methacrylate (PMMA) and tricalcium phosphate (TP) bone cement has already been described in the literature, generally in cadaver models and mechanical tests simulating falls on the greater trochanter.

This study consequently describes the behavior of synthetic bone subjected to a femoroplasty technique, and presents the results simulating falls on the greater trochanter in synthetic bone using PMMA and TP bone cement.

\section{METHODS}

Since this study does not involve humans, ethics committee approval was not required. We used two synthetic proximal femurs (Sawbone 3rd generation, Pacific Research Laboratories, Vashon, WA, USA) with a cortical segment manufactured in 30 pcf solid polyurethane foam and the following properties provided by the manufacturer: Poisson ratio $\sim 0.3$, tensile modulus $\sim 450 \mathrm{MPa}$, and yield strain of $0.7 \%$. The spongy segment consisted of $5 \mathrm{MPa}$ open cell polyurethane foam with the following mechanical properties: Poisson ratio $\sim 0.3$, elasticity module $\sim 5 \mathrm{MPa}$, and yield strain of $3 \%$. The images of this model were obtained before (control model) and after cementing, using helical computed tomography (Toshiba Activion 16/BF, Toshiba Medical Systems, Tochigi, Japan) with the following acquisition parameters: $X$-ray voltage $=120 \mathrm{kVp}$; X-ray power $=250$ BUT; collimation (slice thickness) $=1.0 \mathrm{~mm}$; space between slices $=0.5 \mathrm{~mm}$. Multiplanar reconstructions were performed after image acquisition, as well as volumetric reconstructions. A steel guide wire, cannulated drill bit, and electric drill were used to create three filling holes in the following positions:

Hole I - 25-50 mm from the apex of the greater trochanter using the 2.5 $\mathrm{mm}$ guide wire in the centrolateral aspect of the synthetic model. With the aid of fluoroscopy, the hole crossed two main points in a straight line: one in the upper anterior region of the middle third of the femoral neck, and another in the central portion of the femoral head. Once the correct positioning of the wire on the frontal and axial planes as described above was confirmed, a $5.00 \mathrm{~mm}$ cannulated drill bit was used to perforate the first tunnel. Next, the guide wire was removed and the wire was redirected (using fluoroscopy) through Hole I to create Hole II. Hole II - positioned at an angle connecting two other main points: one in the posterior-inferior region of the medial third of the femoral neck, and another in the posterior inferior portion of the femoral head. Once the appropriate position was determined in the axial and front views using fluoroscopy, a $5.0 \mathrm{~mm}$ cannulated drill bit was used to create the second tunnel.

Hole III - The references for the third hole are the lateral hole, which was already created for the first and second tunnels, and the apex of the lesser trochanter (medial calcar femorale). After fluoroscopy was used to orient and confirm the position of the guide wire to reach these two points, a $5.0 \mathrm{~mm}$ cannulated drill bit was used to create the third hole. (Figures $1 \mathrm{~A}$ and $1 \mathrm{~B}$ )

Approximately $24 \mathrm{ml}$ of TP and PMMA were used separately to fill in the structures in the synthetic model. The cement was injected with a syringe through previously made holes.

To conduct the finite element analysis (FEA), images were obtained before and after femoral reinforcement using Bi-Directional Evolutionary Structural Optimization software (BESO), which has the ability to highlight points with lesser load resistance and add elements in areas of higher mechanical stress, using resistance to traction as a criterion and thus optimizing the areas where cement is applied. This in turn allows the determination of mechanical resistance in Newtons (N) before (Figure 2) and after (Figure 3) reinforcement. The conditions used in the simulations are similar to a fall on the greater trochanter. Increasing force was applied and evenly distributed across the surface nodes of the femoral head.

\section{RESULTS}

Analysis of the synthetic model prior to cementing showed that in the simulated fall, two areas had significant concentrations of stress: one in the upper anterior basicervical region and another in the posterior inferior area of the same region. (Figure 3)

The synthetic model endured a load of $600 \mathrm{~N}$ before cement (control model) after TP was applied this load rose to $920 \mathrm{~N}$, an increase of $53 \%$. When PMMA was used, the load reached $945 \mathrm{~N}$ before collapse, an increase of 57.5\% (Figure 4).

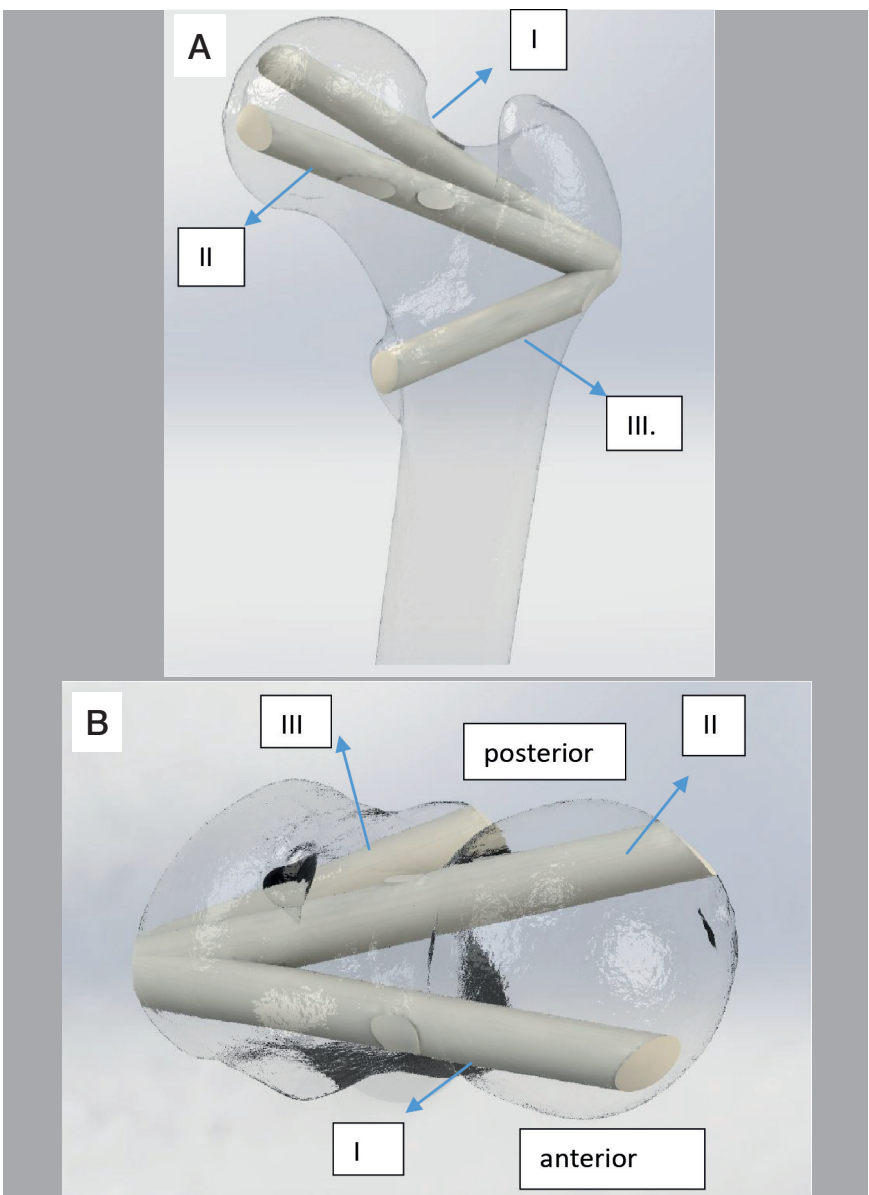

Figure 1. A) anterior view B) axial view, representation and positioning of tunnels I, II and III. 


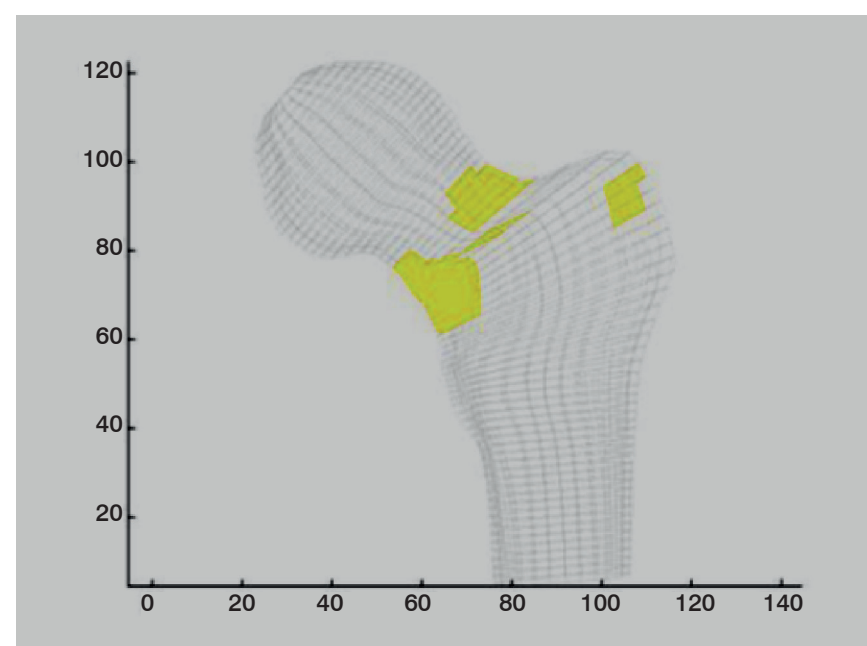

Figure 2. The areas in yellow represent the highest points of tension during FE analysis, in the position of falling on the large trochanter.

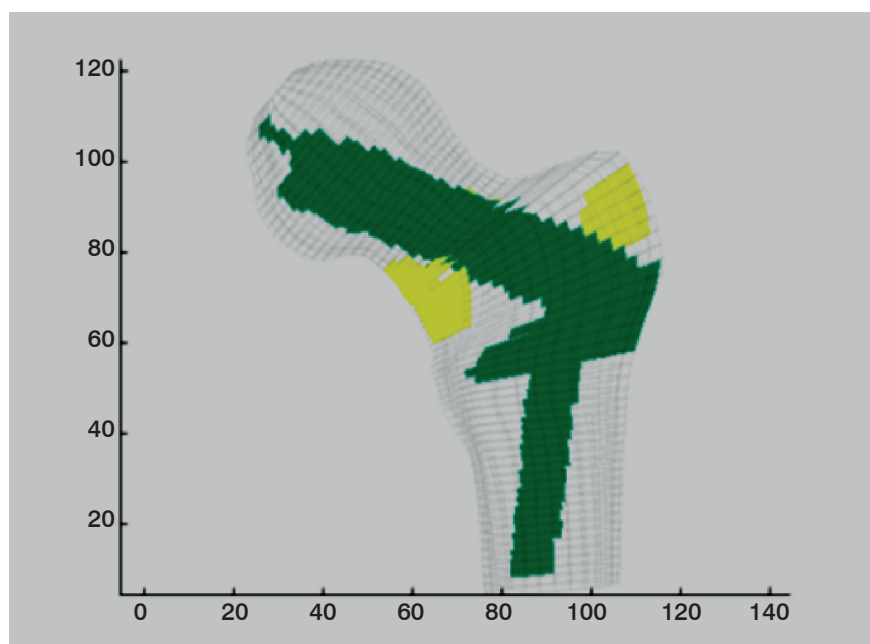

Figure 3. Synthetic model after filling the tunnels with PMMA, represented by green areas, during FE analysis.

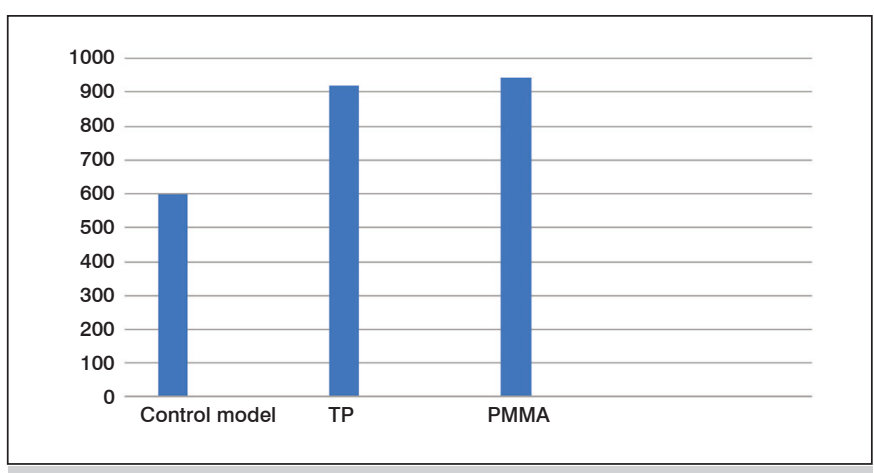

Figure 4. Strength (N) in FE analysis of synthetic models reinforced with PMMA, TP and control model (standard synthetic model, without perforations and without filling).

\section{DISCUSSION}

Reinforcement of the hip bone has already been described in the literature to prevent fractures in focal neoplasia, but its use in preventing osteoporotic fractures requires trials with good levels of evidence to validate results; this is because even though significant improvement has been seen in mechanical resistance, most articles which have been published are experimental studies. ${ }^{8}$

Other studies using PMMA for femoral reinforcement have shown up to $33 \%$ greater bone resistance to fracture, using volumes of cement ranging from 6 to $40 \mathrm{~mL} .^{9-13}$ For TP the additional resistance values varied from 21 to $43 \%$, but the volumes of cement used were not described..$^{14.15}$

It should be noted that the results obtained in this study for increases in bone resistance correspond with previous works in the literature describing both synthetic bone models and cadaverous specimens. The absolute values are lower in cadaver bones, but the relative values are similar. ${ }^{9}$

Some considerations are important when comparing these results with other studies. First, this present study differs in its methodology by using synthetic bones for FEA, a new technique in this field of study

Secondly, FEA was conducted before and after femoral reinforcement, which differs from the methodology in the lines of research used as references, which conducted in vitro stress tests in cadaver bones.

In terms of the evaluation technique, we used a protocol similar to that of Basafa et al., ${ }^{16}$ which was based on FEA to perform optimized and personalized femoroplasty for better results in increased bone strength. However, not all studies followed the same methodology, which complicates comparative analysis and makes it impossible to extrapolate the results.

There is no consensus on the ideal compound for femoroplasty in various studies. Some authors found superior results for PMMA, but did not address the advantages of calcium phosphate, namely its osteointegrative ability and security in terms of not inducing thermal necrosis. ${ }^{15}$

With regard to the cementing technique, the osteoconductive properties of TP immediately restore part of the lost bone mineral content. Furthermore, this compound facilitates the stabilization of fragile cell areas, theoretically increasing the bone matrix, and does not carry the theoretical risk of thermal necrosis caused by the polymerization of PMMA, an undesirable adverse effect in cases with low bone mineral density. ${ }^{9,14}$

Despite the varying methodologies and the lack of multicenter studies, femoroplasty seems to be a viable alternative for preventing fractures of the proximal femur. ${ }^{17,18}$ The development of a standardized methodology would facilitate the progression of this technique and the evaluation of results in future studies. The use of substances with biological properties can theoretically provide even greater benefits for individuals with reduced bone mass.

\section{CONCLUSION}

We observed an increase in resistance to forces causing fracture in synthetic femur bones during simulated falls on the greater trochanter after the use of both PMMA and TP in a pre-defined cementing technique.

\section{ACKNOWLEDGMENT}

Thanks to Prof. Rodrigo Roesler of the Laboratory of Biomechanical Engineering. Hospital Universitário - UFSC- Brazil, for the development of figures $1, \mathrm{~B}$.

AUTHORS' CONTRIBUTIONS: Each author made significant individual contributions to this manuscript. AF (0000-0001-6555-8193)*: drafting and revising the article, cementing procedure; LCS (0000-0003-0006-8139)*, NDVG (0000-0002-3987-5635)*, and APP (0000-0003-3809-2230)*: drafting and reviewing the article; AF (0000-0002-6567-7536)* and MA (0000-0002-1947-9846)*: testing with the computer model. All authors approved the final version of the manuscript. *ORCID (Open Researcher and Contributor ID). 


\section{REFERENCES}

1. World Health Organization: Assessment of fracture risk and its application to screening for postmenopausal osteoporosis. Report of a WHO Study Group. World Health Organ Tech Rep Ser. 1994;843:1-129.

2. Cummings SR, Melton LJ. Epidemiology and outcomes of osteoporotic fractures. Lancet. 2002;359(9319):1761-7.

3. Hernlund E, Svedbom A, Ivergård M, Compston J, Cooper C, Stenmark J, et al. et al. Osteoporosis in the European Union: medical management, epidemiology and economic burden. A report prepared in collaboration with the International Osteoporosis Foundation (IOF) and the European Federation of Pharmaceutical Industry Associations (EFPIA). Arch Osteoporos. 2013;8:136.

4. Lawrence TM, Wenn R, Boulton CT, Moran CG. Age-specific incidence of first and second fractures of the hip. J Bone Joint Surg Br. 2010;92(2):258-61.

5. Ryg J, Rejnmark L, Overgaard S, Brixen K, Vestergaard P. Hip fracture patients at risk of second hip fracture: a nationwide population-based cohort study of 169,145 cases during 1977-2001. J Bone Miner Res. 2009;24(7):1299-307.

6. MacLean C, Alexander A, Carter J, Chen S, Desai SB, et al. Comparative effectiveness of treatments to prevent fractures in men and women with low bone density or osteoporosis. Ann Intern Med. 2008;(148):197-213.

7. Chevalley T, Guilley E, Herrmann FR, Hoffmeyer P, Rapin CH, Rizzoli R. Incidence of hip fracture over a 10-year period (1991-2000): reversal of a secular trend. Bone. 2007;40(5):1284-9.

8. Morgan EF, Bayraktar HH, Keaveny TM. Trabecular bone modulus-density relationships depend on anatomic site. J Biomech. 2003;36(7):897-904.

9. Heini PF, Franz T, Fankhauser C, Gasser B, Ganz R. Femoroplasty-augmentation of mechanical properties in the osteoporotic proximal femur: a biomechanical investigation of PMMA reinforcement in cadaver bones. Clin Biomech (Bristol, Avon). 2004;19(5):506-12.
10. Sutter EG, Wall SJ, Mears SC, Belkoff SM. The effect of cement placement on augmentation of the osteoporotic proximal femur. Geriatr Orthop Surg Rehabil. 2010;1(1):22-6

11. Beckmann J, Springorum R, Vettorazzi E, Bachmeier S, Lüring C, Tingart M, et al. Fracture prevention by femoroplasty--cement augmentation of the proximal femur. J Orthop Res. 2011;29(11):1753-8.

12. Fliri L, Sermon A, Wähnert D, Schmoelz W, Blauth M, Windolf M. Limited V-shaped cement augmentation of the proximal femur to prevent secondary hip fractures. J Biomater Appl. 2013;28(1):136-43.

13. Sutter EG, Mears SC, Belkoff SM. A biomechanical evaluation of femoroplasty under simulated fall conditions. J Orthop Trauma. 2010;24(2):95-9.

14. Strauss EJ, Pahk B, Kummer FJ, Egol K. Calcium phosphate cement augmentation of the femoral neck defect created after dynamic hip screw removal. J Orthop Trauma. 2007;21(5):295-300.

15. Beckmann J, Ferguson SJ, Gebauer M, Luering C, Gasser B, Heini P. Femoroplasty--augmentation of the proximal femur with a composite bone cement--feasibility, biomechanical properties and osteosynthesis potential. Med Eng Phys. 2007;29(7):755-64.

16. Basafa E, Murphy RJ, Otake Y, Kutzer MD, Belkoff SM, Mears SC, et al. Subject-specific planning of femoroplasty: an experimental verification study. J Biomech. 2015;48(1):59-64.

17. van der Steenhoven TJ, Schaasberg W, de Vries AC, Valstar ER, Nelissen RG. Augmentation with silicone stabilizes proximal femur fractures: an in vitro biomechanical study. Clin Biomech (Bristol, Avon). 2009;24(3):286-90.

18. van der Steenhoven TJ, Schaasberg W, de Vries AC, Valstar ER, Nelissen RG. Elastomer femoroplasty prevents hip fracture displacement In vitro biomechanical study comparing two minimal invasive femoroplasty techniques. Clin Biomech (Bristol, Avon). 2011;26(5):464-9. 